argutas dão o tom, ao longo da centena e meia de páginas. Alguns exemplos merecem ser mencionados. Na Hungria, uma entrevistada vê um pequeno e obsoleto automóvel Trabant, fabricado na Alemanha Oriental, que polui oito vezes mais que qualquer carro da Alemanha capitalista e afirma: "um regime que em 30 anos só é capaz de fabricar um Trabant tem alguma coisa de errado. Não há esperança" (p.29). $\mathrm{Na}$ mesma Hungria, outro entrevistado fala que muitos italianos vão para lá atrás das belas mulheres húngaras: "há quem diga que esta diversão é boa e barata e se você não tem mais nada a fazer, é uma bela solução" (p. 35). É bom não esquecer que "Cicciolina" é húngara e faz tanto sucesso na Itália que até foi eleita deputada. Bial e Renée notam os dentes estragados do filho de Tadewzs Mazovietsky, primeiroministro da Polônia e disparam que isso é "um dos sinais mais evidentes e onipresentes da falência do sistema de saude socialista" (p.60). Chamam a atenção para os baixos salários na Romênia, onde um arquiteto de nível ganha menos de 10 dólares por mês (p.77), bem como para o fato de que a Stasi (extinta polícia secreta da RDA) tinha cerca de 200 mil agentes, sem contar os inúmeros informantes. Entretanto, o mais engraçado e curioso pode ser encontrado no capítulo reservado à Albânia, de autoria de Bial, cuja abertura é uma paródia das histórias de Asterix, o Gaulês (p.143). Fala do descontentamento camuflado e medroso da população (p.150); que o sexo antes do casamento é um tabu e que o homossexualismo ainda é "proibido por lei, dá cadeia" (p. 146); que em Tirana, capital do país, todos têm liberdade de ir e vir, "contanto que seja de um lado para outro da praça" (p.144), conforme falam os maldosos. Num momento de exasperação, escreve que "nenhum estado tern competência para cuidar de ninguém", mas que sem a sua intervenção, "os homens simplesmente se devoram". Conclui que é preciso encontrar a terceira margem do rio. "Lembro da anedota moscovita: 'O capitalismo é o sistema da exploração do homem pelo homem. O comunismo é exatamente o contrário...' "(p.155). $\square$

\section{COMISSÃO DE FÁBRICA E TRABALHADORES NA INDÚSTRIA}

IRAM JÁCOME RODRIGUES

São Paulo, Cortez, 1990,

172 páginas.

\section{Por Fernando C. Prestes Motta}

Professor Titular do

Departamento de Administração

Geral e Recursos Humanos da

EAESP/FGV.

Não é mais um livro sobre participação. Trata-se de um trabalho que, salvo melhor juízo, já surge como leitura inevitável para a pesquisa e compreensão das relações de trabalho no Brasil. Iram Jácome Rodrigues, professor da Faculdade de Economia e Administração da Pontifícia Universidade Católica de São Paulo, em Comissão de fábrica e trabalhadores na Indústria analisa com impecável fundamentação teórica e invejável discernimento um dos fatos novos das relações de trabalho em nosso país, algo que entra na cena política do final dos anos setenta e nos anos oitenta, qual seja, a organização dos trabalhadores a partir do local de produção, instituindo organismos de representação operária conhecidos como comissões de fábrica, de forma semelhante ao que vem caracterizando o movimento operário, pensado em termos do capitalismo internacional.

Desempenhando papel significativo nas greves da região do $A B C$ paulista nos últimos anos da década dos setenta, essas comissões de fábrica apresentam-se, por vezes, como autônomas face aos sindicatos operários respectivos e, por vezes, fortemente a eles vinculadas, no que se refere à sua atuação. $\mathrm{Na}$ medida em que tais organismos não eram previstos pela legislação sindical, podendo, portanto, agir de forma muito mais dinâmica do que o sindicato, não eram restringidos nem por ele, nem pelos orgãos governamentais, tais como o Ministério e a Justiça do Trabalho.

Leôncio Martins Rodrigues tece essa consideração na apresentação do livro, salientando o caminho percorrido pelo autor na análise da comissão de fábrica em uma das grandes montadoras da indústria nacional naquela virada de década.

A questão dos sindicatos atrelados ao Estado, possibilitando a coerção paternalista exercida pelo segundo em relação ao primeiro, é algo que precisa sempre ser considerado no exame de estrutura sindical brasileira. Esse fato tem sido evidenciado em um bom número de estudos sobre sindicalismo e relações de trabalho em geral, entre os quais estão análises realizadas por Azis Simão, Heloisa Helena de Souza Martins e Sérgio Amad Costa. Essa situação, como demonstra o estudo de Iram Jácome Rodrigues, convive com movimentos tendentes à criação de formas autônomas de organização. É isso que torna possível vislumbrar manifestações de resistência e Iuta, de afirmação de verdadeira cidadania, de comunicação, negociação de reivindicação e cooperação que coexistem no campo de força das relações de traballho, em núveis de complexidade e organização diversos.

É importante observar o caráter democrático que a comissão de fábrica tende a assumir na luta operária. Pensando em casos diversos, brasileiros e outros, ela parece significar a substituição de relações entre desiguais por relações entre iguais. Isto ocorre tanto entre os muros da fábrica como nas demais instituições sociais. A dialética permeia as relações de dominação e resistência nas organizações de sociedade capitalista. Historicamente, os trabalhadores têm Iutado pela democracia, sob forma de comissão de fábrica ou conselho operário, onde o poder é atributo das assembléias gerais, eixo central tanto dos debates quanto das decisões. Muitos estudiosos entendem que é a estrutura interna dessas comissões, bem como seus objetivos e atividades, que definem seu caráter. Essas considerações referem-se naturalmente às comissões de fábrica em situações muito diversas. Servem, entretanto, de pano de fundo para o caso que Iram Jácome Rodrigues tão bem descreve e analisa.] 